\title{
EchoGéo
}

35 | 2016

Les découpages territoriaux en Europe

\section{Administrative division of Poland - 25 years of experience during the systemic transformation}

Tomasz Kaczmarek

\section{Q OpenEdition}

1 Journals

Édition électronique

URL : https://journals.openedition.org/echogeo/14514

DOI : $10.4000 /$ echogeo. 14514

ISSN : 1963-1197

Éditeur

Pôle de recherche pour l'organisation et la diffusion de l'information géographique (CNRS UMR 8586)

Référence électronique

Tomasz Kaczmarek, «Administrative division of Poland - 25 years of experience during the systemic transformation », EchoGéo [En ligne], 35 | 2016, mis en ligne le 19 avril 2016, consulté le 10 août 2021. URL : http://journals.openedition.org/echogeo/14514; DOI : https://doi.org/10.4000/echogeo.14514

Ce document a été généré automatiquement le 10 août 2021.

EchoGéo est mis à disposition selon les termes de la licence Creative Commons Attribution - Pas d'Utilisation Commerciale - Pas de Modification 4.0 International (CC BY-NC-ND) 


\title{
Administrative division of Poland - 25 years of experience during the systemic transformation
}

\author{
Tomasz Kaczmarek
}

\section{Introduction}

In passing from communism to democracy and a market economy, one of the goals of the transformation in Poland was the decentralisation of power and administration via the restoration of territorial self-governance ${ }^{1}$ and a new territorial framework for its operation. In 2015 it has been 25 years since the return of territorial self-government institutions to the commune level. The reform of the management of local units was an impulse for further decentralisation, which took place in 1999 at the intermediate level of administration, that of the poviat, and the regional one, that of the voivodeship. This two-stage reform has changed the country's administrative division. It has become one of the fundamental attributes of decentralised public administration, while also providing a spatial framework for the operation of the economy, social life, and citizen activity (Sack, 1986).

2 The increase in the requirements that public administration is supposed to meet makes it necessary for it to improve its efficiency steadily, also through the rationalisation of its territorial structure so as to match the changing spatial-functional systems. There are a variety of factors that have an impact on the administrative division, both internal, connected with demographic and settlement-related changes (spatial development, mostly of large cities), and external ones, like the globalisation of the economy and the policy of the European Union. Their effect has been differences in the dynamics of demographic and socio-economic development of territorial units, with regional convergence processes supported from the EU structural funds intended to level them out. It is not surprising, therefore, that with time there have appeared voices about the need to correct, or even reform, Poland's territorial organisation. The 
empowered communities of territorial units have a growing sense of localism (or regionalism) and defend their right to self-determination, while those that have no self-governing representation demand corrections in the territorial division and a right to self-governance.

3 This article presents the chief features of Poland's administrative (territorial) division and makes its assessment at its three levels: that of the voivodeship, the poviat, and the commune. The assessment criteria are the number and size of administrative units, the course of their boundaries, and selected relations between the territorial structure and socio-economic processes taking place in Poland over the last 25 years. The reference point is also the territorial divisions of other EU states, especially those that, like Poland, have a three-tier structure.

4 The basic thesis of the paper is that the territorial organisation of public administration should change to keep pace with political, economic, social and spatial processes, the last being especially significant for it (Kaczmarek, 2005). Their dynamics over the last 25 years invites reflection on a further transformation of the country's territorial organisation. The article ends with conclusions and recommendations concerning the directions of change in local administrative structures. Methodically the paper is based on a review of the most important national and foreign literature, government reports and expert opinions on the territorial division and the most important legislation on this issue.

\section{The administrative division in the light of analyses and assessments}

5 At the commune level, Poland's territorial structure in its present form is the effect of the 1973 territorial reform and the first stage of the 1990 self-government reform, with slight modifications until the present. At the poviat and voivodeship levels, the current administrative division is a result of stage two of the 1999 self-government reform. The Act of 24 July 1998 introducing the state's fundamental three-tier territorial division provides that the division units are communes, poviats and voivodeships. When the division came into force on 1 January 1999, it included 16 voivodeships, 373 poviats (65 municipal and 308 non-municipal ones), and 2489 communes. As of 1 January 2015, Poland's basic territorial division included:

- at the regional level, 16 voivodeships,

- at the subregional level, 380 poviats, including 66 poviat-ranking towns (municipal poviats) and 314 non-municipal poviats, and

- at the local level, 2,478 communes, of which 304 urban, 611 urban-rural, and 1,563 rural ones.

6 Thus, Poland's administrative division has been fairly stable since its introduction and has undergone only slight modifications so far. The number of voivodeships has not changed, but 7 new poviats and one new commune have been established, while 12 communes have been liquidated (over the last 10 years).

7 In the public opinion poll of 2000 , out of the four social reforms implemented by that time: of the retirement system, schooling, health service, and the decentralisation of public administration, it was the self-government reform that was rated the highest (Cztery reformy..., 2000). Since the reform, territorial governments have enjoyed great 
social trust, much greater than central administration. A 2004 study showed $52 \%$ of those examined to express trust in local authorities, while only $21 \%$ trusted either of the central authorities - the Parliament and the government. By comparison, trust in the European Union was then declared by $46 \%$ of respondents (Zaufanie..., 2004). A similar study conducted in 2014 showed trust in public institutions to have risen in Polish society. Territorial governments enjoyed the trust of as many as $60 \%$ of those polled, while the Parliament earned $34 \%$, the government, $33 \%$, and the European Union, 68\% (Stosunek..., 2014). Since a territorial government acts within specified boundaries, it seems that Poles are also satisfied with this aspect of its operation. Even before the introduction of the three-tier territorial division, a substantial proportion of society ( $40 \%$ ) definitely opted for reducing the number of voivodeships (there were 49 of them then) and for creating an intermediate unit - a self-governing poviat (Polacy o reformie,... 1998).

The Polish administrative division has been an object of many analyses and assessments in academic literature, both at the time of its transformation (e.g. Chojnicki, Czyż, 2000; Karliński, Nelicki, Płoskonka, 2000, Kaczmarek 2001, Ocena ..., 2001, Miszczuk 2003), and after a longer period (e.g. Izdebski 2009; Zaborowski, 2009; Ustrój..., 2012 ; Walczak, 2012). Most of the references quoted corroborate the directive formulated in Art. 15, Section 1. of the Polish Constitution: "The territorial form of government of the Polish Republic ensures the decentralisation of public authority". But one of the conclusions that can be drawn from the assessments made so far is that Poland's present territorial division no longer fully matches the needs and challenges of the country's development. Therefore, in the opinion of many authors, it is not an optimum spatial-functional construction when considered in terms of tasks assigned to public administration and the imperative recorded in Article 15, Section 2 of the Polish Republic's Constitution concerning the ability of territorial units to perform public tasks.

There has also been a change in the diagnosis of the territorial division made by state institutions. In 2000 the Polish Republic's Council of Ministers decided the new administrative division to be correct. But even then it was considered necessary to take steps to unite poviat-ranking towns and poviats having seats of their authorities in those towns, and making necessary corrections of the existing territorial division with a view to eliminating local conflicts, strengthening social links, and better use of public means. In 2001 the Sejm and Senate in unison decided the state's new basic territorial division to meet the assumptions of the public administration reform ${ }^{2}$.

The 2013 Report of the Ministry of Administration and Digitisation (Ocena ... 2013) states that "Several communal and poviat governments are small and financially weak units. In time they may not be able to bear the more difficult and costly public tasks for the senescent country". Also the Report on the state of territorial self-governance in Poland (2013) claims that "demographic processes will increasingly undermine the financial foundations of the operation of the smallest self-governing communities, increasingly burden the state budget with transfers to self-governments, and undermine their ability to offer public services".

11 Without going into the details of the above assessments and standpoints, this paper focuses on the evolution of Poland's territorial-administrative structure over the last 25 years and presents its key problems significant also in terms of future changes. 


\section{The territorial division of Poland against the backdrop of other European countries}

One of the criteria employed to assess Poland's territorial division is a comparison with the administrative structures of other states, especially those that have built local and regional democracy much longer than Poland.

With its three tiers of administration (voivodeship-poviat-commune), Poland is one of the 13 European countries with such a complex territorial structure. In the European Union, a similar system can be found in 11 countries (table 1). There are three levels of territorial administration in both federal and unitary countries. This territorial structure model is generally characteristic of countries that are large and have a considerable population number. Poland meets these conditions, being eighth in Europe in terms of population (38.5 million) and ninth in terms of area (312.7 thous. $\mathrm{km}^{2}$ ). As to the population number, a Polish voivodeship is comparable with regions of large EU countries (behind Germany and Italy, before Spain and France). Similar considerable differences in the population or area as those among Polish voivodeships (e.g. small voivodeships: Opole or Lubuska Land versus large voivodeships: Mazovia or Silesia) can also be found in other European countries. The mean values of regional units in individual countries do not reflect their internal differences. They are especially visible in the case of the areas of regional units. An extreme case is Germany, where both towns (Stadtland) and large Länder (Flächenland) can have the status of states. In this way the smallest Bremen is 0.4 thous. $\mathrm{km}^{2}$ in area, and Bavaria - ca. 70 thous. $\mathrm{km}^{2}$ (a 1:150 proportion). In Italy, the Aosta Valley region situated in the north has a mere 3.3 thous. $\mathrm{km}^{2}$, while Sicily in the south - 26 thous. $\mathrm{km}^{2}$ (1:8). In France, the Alsace region has 8 thous. $\mathrm{km}^{2}$ as against 45 thous. $\mathrm{km}^{2}$ of the Midi-Pyrénées (1:6), while in Spain the Basque Country occupies 7 thous. $\mathrm{km}^{2}$ and the Castile-Leon region, 94 thous. $\mathrm{km}^{2}$ (1:13). Against this background the differences in the area of Polish voivodeships do not seem so wide. The smallest region - Opole voivodeship - has an area of 9.5 thous. $\mathrm{km}^{2}$, while the largest one - Mazovia - has 35.6 thous. $\mathrm{km}^{2}(1: 4)$.

When the size of a region is measured by the number of its inhabitants, regions tend to be the largest in countries with a complex (three-tier) territorial structure and usually big in area. This means at least 2 million people on average and the area exceeding 10 thous. $\mathrm{km}^{2}$. Exceptions are only small Central European countries: the Czech Republic and Slovakia, for which a three-tier territorial division means a strong fragmentation of units, both at the regional and local levels.

Table 1 - Mean size of a region in selected European Union countries

\begin{tabular}{|l|l|l|}
\hline Countries & Population $(\mathbf{m l n})$ & Area (thous. $\left.\mathbf{~ k m}^{\mathbf{2}}\right)$ \\
\hline Great Britain * & 14.6 & 61.0 \\
\hline Germany * & 5.1 & 22.3 \\
\hline Belgium * & 3.4 & 10.3 \\
\hline Italy* & 2.9 & 15.1 \\
\hline
\end{tabular}




\begin{tabular}{|l|l|l|}
\hline Poland* & 2.4 & 19.5 \\
\hline Romania* & 2.4 & 29.6 \\
\hline Spain* & 2.3 & 29.4 \\
\hline France* & 2.2 & 20.9 \\
\hline Netherlands & 1.3 & 3.5 \\
\hline Austria* & 0.9 & 9.4 \\
\hline Greece & 0.8 & 10.2 \\
\hline Denmark & 0.4 & 3.1 \\
\hline Ireland & 0.4 & 8.8 \\
\hline Slovakia * & 0.7 & 6.1 \\
\hline Czech Republic* & 0.7 & 5.7 \\
\hline Sweden & 0.4 & 22.5 \\
\hline Finland & 0.3 & 17.8 \\
\hline
\end{tabular}

* = countries with a three-tier territorial division.

Source: own calculations on the basis of data of the European Commission and the EU Committee of the Regions.

15 In countries with territorial administration expanded to three levels, the size of an intermediate unit, like a poviat, province, department or district, also varies (Table 2). A certain regularity can be observed here. The countries that have introduced a departmental division modelled after the French pattern (apart from France, also Spain, Italy, Belgium, the Netherlands, Portugal and Greece), have an intermediate unit strong in terms of size and population number. Until the regionalisation, in some of them those units played a key role at the sub-state level of administration, performing some regional tasks.

What should be emphasised is the weak position - a small size - of the Polish poviat (the area, population number) against second-level units of administration in the other large European countries with a three-tier structure of territorial administration (table 2).

Table 2 - Mean size of the subregional unit in selected European Union countries

\begin{tabular}{|l|l|l|}
\hline Countries & Population (thous.) & Area $\left.\mathbf{( k m}^{\mathbf{2}}\right)$ \\
\hline Belgium * & 1013 & 3100 \\
\hline Spain * & 783 & 10120 \\
\hline
\end{tabular}




\begin{tabular}{|l|l|l|}
\hline France * & 580 & 5440 \\
\hline Italy* & 558 & 2925 \\
\hline Portugal & 551 & 5132 \\
\hline Great Britain* & 502 & 2104 \\
\hline Romania & 460 & 5820 \\
\hline Greece & 205 & 2588 \\
\hline Germany* & 186 & 813 \\
\hline Czech Republic* & 134 & 1024 \\
\hline Poland* & 104 & 838 \\
\hline Slovakia* & 68 & 620 \\
\hline
\end{tabular}

*=countries with a three-tier territorial division.

Source: own calculations on the basis of data of the European Commission and the EU Committee of the Regions.

17 In characterising the territorial division of Poland against the background of other EU countries, worth noting is also the so-called 'management range', or the number of territorial administration levels and the corresponding administrative units (cf. Kaczmarek, 2001). A measure here is the average number of lower-level units per a higher-level one. In Poland the relation 1 (voivodeship): 23 (poviats in a voivodeship): 7 (communes in a poviat) much departs from the proportions found in other European countries with a three-tier structure. In Germany those relations are 1: 27: 33, in Belgium 1: 3: 59, in Italy 1: 5: 79, in Greece 1: 4: 106, in Spain 1: 3:161, and in France 1: 4: 365. Thus, in those countries a 'pyramid' system prevails, with small communes at the base and fewer large subregions at the higher management level (units of the department/ poviat/ province type). Assuming this model of 'management range' to be common in Europe, Poland's administrative division must be seen as having too great a number of poviats as intermediate units of self-government administration.

\section{The territorial division into communes}

18 The number and size of administrative units at the local level are among the key problems concerning territorial structures and their transformation. As Mouritzen (1989) observes, this question has been discussed animatedly from the times of the Greek polis to present-day debates on the purpose and character of territorial reforms. In modern research on the size of local units, the key issue is relations between the size of a commune on the one hand and the efficiency of local authorities in performing public services and the participation of local communities in public life on the other. Discussions on this matter have been going on since the 1950s when several European countries decided to rearrange their local territorial structures. With the introduction of the first territorial reforms in postwar Europe, the relationship between an increase 
in the operating efficiency of local units as they grew in size and a weakening of citizen participation in public life became readily visible (Sharpe 1995). Where the local units are large (the Scandinavian states, Great Britain, the Benelux states), the scope of their competence is considerable. There appear economies of scale in performing many services, and local units have more financial means at their disposal, drawn largely from their own incomes. In spite of their highest spending per inhabitant, small communal governments have no great development capacities and are not able to influence the quality of life of their residents directly. A bigger size of a unit makes a local policies easier to implement and reduces the unfavourable spillover effect, i.e. the mismatch between places offering services and places of residence and paying taxes in a commune (Keating, 1995; Kaczmarek, 2005; Territorial ... 2010).

Poland's territorial structure at the commune level in its present form is an effect of the 1973 reform when the Soviet model of small local units (gromady) was replaced with multi-village communes. The consolidation of communes in 1973 turned them into socio-economic micro-regions with a central rural or urban core and a local settlement system embracing an average of dozen-odd villages. The division into communes made then has survived in its basic form until today. As a result of the self-government reform of 8 March 1990, 2,121 communes obtained a local government status with elective authorities. Since 2002 local communities have elected not only members of commune councils but also one-person organs leading them: the wójt (the head of a rural commune), the burmistrz (the mayor of an urban-rural or urban commune), and the president (larger towns). The division into rural, urban-rural and urban communes is purely formal and does not involve a different organisation of the local authority. This is a consequence of the uniformity of systemic solutions concerning the legal status of communal self-government units. Only larger towns (66) - mostly over 100 thous. inhabitants - perform the tasks of both communal and poviat levels (poviatranking towns).

In terms of changes in local territorial structures after the period of the systemic transformation, the most significant has been an increase in the number of communes. This was due to the fragmentation of communes as a result of the democratisation of public life after 1990. This process seemed unavoidable ${ }^{3}$. The restoration of territorial self-governance, free elections to local authorities, the rebirth of local patriotism, and the initial lack of a state vision concerning the transformation of territorial administration at higher levels were the chief factors of the appearance of new communes. In the absence of serious statutory limitations as to the partitioning of communes in the first half of the 1990s, between 1990 and 2000 the number of communes grew spontaneously from 2,121 to 2,489 , i.e. by $17 \%$. Among the reasons of the fragmentation of communes the following should be mentioned:

1. the absence of statutory regulations as to the criteria of the division of communes, which caused this division to take place in a spontaneous and uncontrolled way;

2. the appearance of new local units as a manifestation of bottom-up social movements and the democratisation of life in the new systemic conditions;

3. the restoration of communes that once disappeared from the administrative map as a result of consolidation reforms; and

4. divisions of local units for political reasons following from differences in opinions about the development of communes in commune councils and their corresponding territories. 
21 divisions of towns and communes artificially united before 1989 (so-called 'conglomerate towns' - Szmytke 2009). Hence the restorations of self-governing communes involved mainly suburban ones previously incorporated into towns. This could especially be observed in Upper Silesia, where neighbouring rural communes were made parts of towns in the 1970s and '80s (Kaczmarek, 2005).

New communes stopped being established after 1998 with the restoration of the second tier of local self-government: the poviat. Then the Council of Ministers introduced stricter criteria of the creation of communes that took into consideration demographic, infrastructural and economic factors. A more rigorous interpretation was given to the provisions of the Communal Self-Government Act (Art. 4 Section 3) demanding maximum uniformity and territorial cohesion as well as the ability to perform public tasks. Applications to reactivate communes increasingly met with a negative decision of the opinion-giving organ. The standpoint of the Ministry of the Interior and Administration was that the division of a commune was contrary to the state policy of keeping units large and strong, because such units had greater budgetary possibilities, were better able to absorb Community means, and used public means more efficiently. In the years 2002-2015 only one commune was created in Poland: Jaśliska in Subcarpathian voivodeship.

In the Communal Self-Government Act currently in force, Art. $4 \mathrm{~d}$ says that the Council of Ministers will not consent to create communes in which:

1. tax revenues per inhabitant of a commune with changed boundaries or a newly created commune would be lower than the lowest tax revenues per inhabitant established for individual communes, and

2. the commune in the altered boundaries or the newly created commune would be smaller than the smallest commune in population terms in Poland.

Those two provisions are a significant barrier to setting up communes, dwarfish and economically inefficient in the Polish conditions, especially after the introduction, as an amendment to the Communal Self-Government Act of 2011, of rules allowing residents to come out with an initiative to create, combine, divide or liquidate a commune and to delineate its boundaries. It takes the form of a local referendum.

In terms of the rationalisation of public management, the most debatable is the fact that 158 rural communes (about 10\%) have seats located in neighbouring urban communes. The office of such a commune is often located not only in the same town as the town office headed by a mayor or president, but even in the same building. The existence of a rural commune, especially small, around a separate urban unit is irrational in that most services are concentrated and performed in the town that is the central unit also for the rural hinterland. Thus, a rural commune has a political rather than an economic justification. As Walczak (2012) observes, the simultaneous operation of both those entities makes it necessary to keep a double self-government administration and worsens the coordination of physical development measures, strategies and plans. In the case of larger cities, this also means economic problems caused by the transfer of investment (housing- and production-related) into rural areas. Any changes, or even their discussion, are often treated by rural communes as an attack on their self-governance. Their inhabitants also worry about a possible increase 
in the agricultural tax or the real estate tax. In principle, there are three steps possible as a way out of this situation:

1. unifying the urban and the rural communes into an urban-rural one;

2. incorporating the rural commune into the boundaries of the town and creating one large urban commune; and

3. incorporating some parts of the rural commune into the town while preserving both selfgoverning units in modified boundaries.

Gustafsson, 1992; Mouritzen, 1989; Consolidation or fragmentation, 2002) that a fragmented territorial organisation of communes gives rise to many problems: structural-economic (the efficiency and economics of scale of the operation of an administrative unit), financial (no self-sufficiency, no own income, no ability to finance investment), and political (the necessity to cooperate with neighbouring units). Taking into consideration those factors, territorial-administrative changes are expected to bring specified political, economic and social effects. A bigger size of units facilitates conducting a local development strategy and reduces the unfavourable spillover effect, i.e. the mismatch between places in a commune offering services and places of residence and tax payment (Keating, 1995). Thus, the basic goal of the reorganisation of communes is to strengthen local democracy and to ensure residents a greater influence on how to solve local problems in their living environment.

\section{The subregional level: poviats and metropolitan areas}

One of the most controversial questions in Poland's territorial division is its poviat structure and the territorial organisation around the largest cities (metropolitan areas). In 2000 the government decided it was necessary to take urgent steps to merge poviat-ranking towns and poviats that had seats of their authorities in those towns because of considerable disparities in the institutional potentials of those two types of poviat units. Government analyses showed the potential of poviat-ranking towns to be significantly higher and the potential of poviats with no major urban centres to be particularly low. Especially non-municipal poviats with no medium-sized and large 
cities had definitely poorer resources to perform poviat-level public tasks. It was emphasised that non-municipal poviats around medium-sized towns had no major incomes of their own and no higher-order services, concentrated in central places. A reduction in the number of poviats should therefore first involve the unification of weak urban and rural poviats.

In 2001 polish parliament - the Sejm decreed it necessary to support initiatives intended to rationalise the country's territorial division into poviats, and judged some poviats to be too weak in economic terms and hence rather inefficient. An analysis of the development potential of poviat units showed there to be wide differences between poviat-ranking towns and poviats with no urban centres. The Sejm decided that the unification of poviat-ranking towns with the surrounding poviats having seats in those towns would be favourable for the performance of a public function. To date, there has only been one fusion of a poviat-ranking town with a non-municipal poviat (Wałbrzych and its poviat). This experiment survived a mere 10 years (2003-2012). As a result of financial analyses, it was decided that dividing the new single poviat again was economically more viable.

One of the key unresolved problems of the administrative structure in Poland is the territorial organisation of urban regions. As Izdebski (2012) observes, a three-tier territorial-administrative division - like the one in force since 1998 - does not rest on the polarisation-diffusion development model adopted in advanced countries. In this model a special development role - of places of a development potential concentration is assigned to urban areas, in particular metropolitan areas which by their very nature should perform selected regional functions. Those functions are identified in terms of the statistical standards of the European Union at the NUTS 3 level of regions.

In Poland, urban agglomerations are organised, as in Germany, in accordance with the poviat model, i.e. a big city is a poviat-ranking commune (e.g. Cracow, Poznan, Wrocław, Łódź). The administrative division around a big city is either concentric, i.e. there is one poviat surrounding the city (e.g. Poznan poviat) or sectoral, with the city bordering on several poviats (e.g. Warsaw with 7 adjoining poviats, or Wrocław, tódź, Cracow). Some peri-urban poviats have seats in the central city.

In an urban agglomeration the division of competences of a poviat between two or usually more administrative units gives rise to many planning and administrative problems. They are even greater at the level of the commune. There are tens of communes around large cities differing in economic potential, investment attractiveness, etc. Mutual competition and different interests in relations with a large city make closer cooperation within the entire metropolitan area difficult, if not altogether impossible. Neighbouring units prepare separate, poorly coordinated planning documents and follow different, often contradictory, antagonistic development strategies. Today towns and their surrounding communes form rare constellations of associations and agreements, often single-task ones and differing in spatial range. The limited competences of fragmented poviats are not an integrating factor here.

One of the proposals for an improvement of this state of affairs is the separation of the status of metropolitan areas in the self-government administrative system. In the years 2007-2015 there appeared five proposals of acts regulating this status. They generally sought to establish a level of metropolitan self-government and to give its authorities competences and means of both communes and poviats as well as some competences of 
the voivodeship level. This is similar to the situation in the administrative systems within some urban regions in Germany (e.g. the Hannover Region).

On 9 October 2015 the Sejm passed the Metropolitan Associations Act that gives functional urban areas with at least 500 thous. inhabitants some local-government tasks: organising public transport and creating supra-local physical planning documents (metropolitan studies). This act, important and awaited by local governments, still had no executive regulations when this article was being written.

Worth noting is the growing number of bottom-up forms of metropolitan integration in Poland (see Kaczmarek, Ryder, 2015 for more). For example, the Poznan Metropolis Association set up in 2011 declares in its statute that it will seek to establish a poviatcommune metropolitan association for which the target model is a future metropolitan poviat. For several years the Association has pursued a common development strategy and coordinated the spatial policies of communes, and primarily has been a beneficiary of the European funds within the framework of the Integrated Territorial Investment instrument. The key investment within this framework has been the Poznan Metropolitan Railway. ITI means are absorbed by 18 communal associations clustering around all voivodeship capitals.

There is, therefore, a chance that the systemic model of metropolitan associations will be introduced in Poland, which has not succeeded in many European countries so far (cf. Norris, 2001; Local Power ..., 2000; Metropolitan governance ..., 2005). After more than ten years of useless discussion, the inauguration of metropolitan associations in 2016 will be a serious step towards the integration of the management of big cities and their functional areas.

\section{The regional level: voivodeships}

38 In the case of Poland, one can advance political, economic, and social arguments for the introduction of the regional reform in 1999. In political terms, it was a continuation of the systemic transformation of the 1990s and the programme of the decentralisation of power, the development of territorial self-governance, and the democratisation of public life. An important inducement for regionalisation was also the prospect of Poland's membership of the European Union and an adjustment of its territorial structure to standards obtaining in large, regionalised states. In economic terms, the territorial reform has become a key element allowing better management of public funds, a better operation of offices and institutions performing public services, the introduction of regional policy rules, and greater competitiveness of regions in the supra-national dimension. The social aspect of the reform was an acceleration of the building of a civil society, an increase in the level of social control over budgetary means, and the possibility of articulating political programmes at levels between the commune and the Parliament.

39 In assessing Poland's territorial division at the regional level, one should note pragmatic effects achieved after its introduction in 1999. Those are, among others:

- ensuring the state better organisational and operational conditions,

- liquidating internal barriers to the development of a regional economy,

- more efficient operation of the country's settlement system,

- more efficient use of the state budget, 
- creating conditions for the development of international cooperation at the level of regions,

- greater possibilities of the development of a civil society and an increase in the democratisation of public life, and

- creating foundations for a regional policy consistent with the assumptions of the European Union's structural policy.

Regional selfgovernment, despite the limited tasks, thanks to the redistribution of about $25 \%$ of EU aid for Poland, plays an important political and symbolic role in the process of political decentralisation. Poland is currently divided into 16 voivodeships (Polish: województwo). Previously (in the period from 1975 to 1998) there had been 49 smaller voivodeships (see illustrations 1 \& 2). Administrative authority at voivodeship level is shared between a central government-appointed governor, called the voivode (usually a political appointee), an elected assembly called the sejmik, and an executive chosen by that assembly. The leader of that executive is the marshal (Polish: marszałek).

When assessing the country's division into voivodeships, the most debatable is the number of those units and hence the course of their boundaries. When the system of 16 voivodeships came into force, it was not fully accepted by society, especially in regions with long administrative traditions (Koszalin voivodeship, 1956-1975, divided in the years 1975-1998 into Koszalin and Słupsk ones). Also in regions with wide and growing development disparities (Warszawa and the remaining part of Mazowieckie voivodeship) a discussion has recently been going on about the detachment of Warszawa as a separate unit at the regional level (a capital voivodeship).

Illustration 1 - The 1999 reform of the administrative division into voivodeships

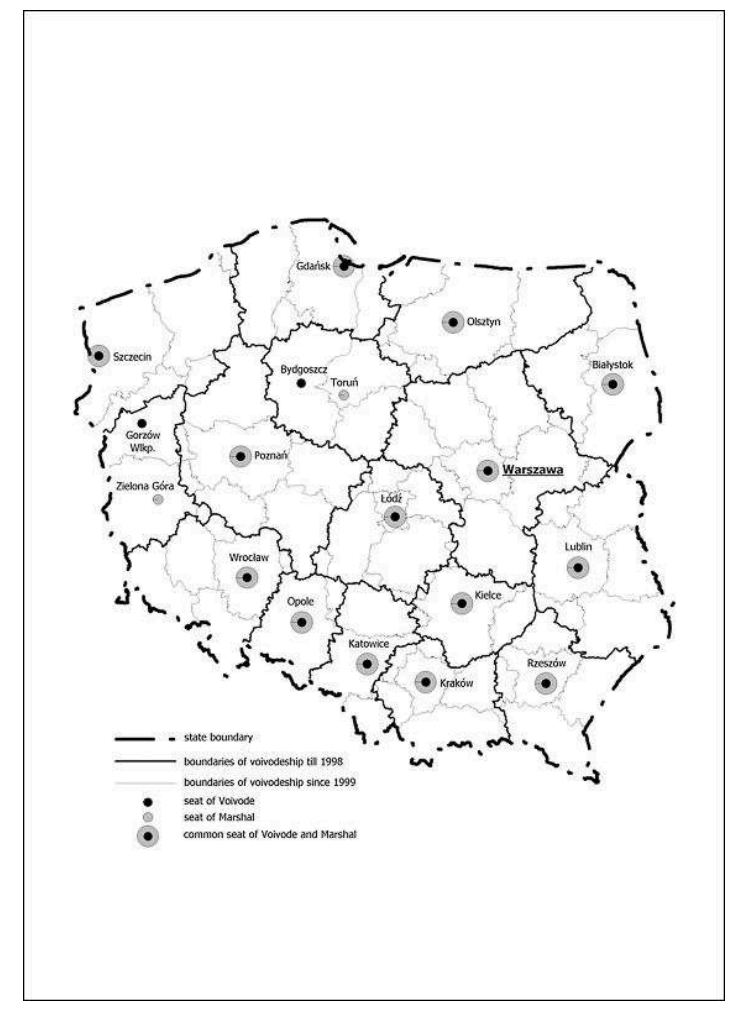

Source: compilation of the author. 


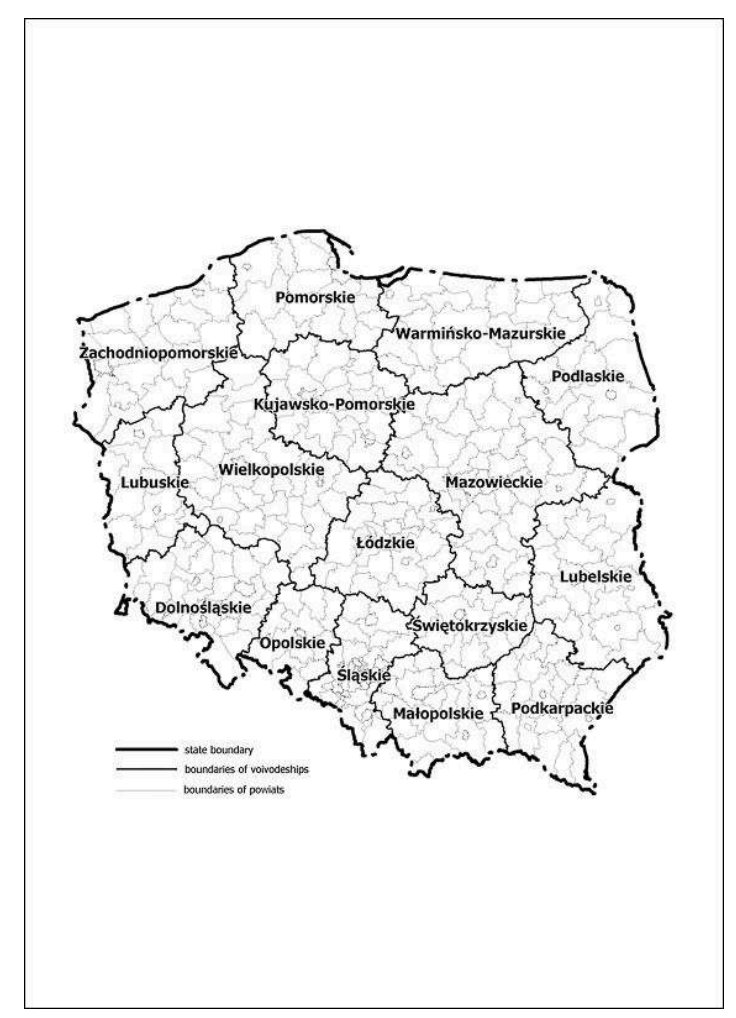

Source: compilation of the author.

42 The liquidation of Koszalin voivodeship in North Poland in 1999 was opposed by its inhabitants, who opted for the establishment of a voivodeship of Central Pomerania, but the discussion, in spite of the involvement of the local circles, has not yet led to any changes on the country's administrative map. In 2000 a study was conducted on the administrative preferences of inhabitants of the Central Pomeranian region. It embraced 2,483 respondents living in the former (1975-1998) Koszalin voivodeship and 2,316 residents of the former Slupsk voivodeship. It showed $75 \%$ of the respondents opting for the creation of a new voivodeship of Central Pomerania (Partacz 2005). In 2003 procedures were started for the creation of a Central Pomeranian voivodeship under a citizen initiative known as the Integration for Development Association.

On 2 March 2006 the Council of Ministers spoke against the project of establishing a new voivodeship because of the significant increase in the administration's operational costs this would produce. In turn, proponents of Central Pomeranian voivodeship quote the official position of the government in which it proclaims "special protection of the constitutional rights of local and regional communities to participate in the exercise of power" and recommends that the Sejm should hold a referendum in the area of the proposed voivodeship. They also worry about the peripheralisation of the Central Pomeranian region, e.g. through the drainage policy that the authorities of Pomeranian and West Pomeranian voivodeships carry out here (draining funds, human capital, or even material resources). The question of Poland's 17th voivodeship comes up especially in electoral campaigns to the polish parliament. This was also the case in the parliamentary campaign of 2015 , so the question seems to be open all the time. 


\section{Summing up}

The fundamental conclusion following from the above reflections is the following: public administration should change to keep pace with political, economic and social processes. An increase in the efficiency of public management makes it necessary to rationalise territorial structures and calls for greater elasticity of legal rules (e.g. concerning the cooperation of self-government units) and the establishment of territorial frameworks adjusted to the new spatial-functional systems. The rationalisation need not involve another big territorial-administrative reform. While one of the fundamental conditions of a good operation of a territorial system is its stability, this does not preclude corrections and modifications.

45 The Constitution of the Polish Republic (Art. 15, Section 2) provides that the state's basic territorial division must take into consideration social, economic and cultural links, and ensure territorial units the ability to perform public tasks. With this provision in force, it is necessary to work out a document that would analyse the advantages and disadvantages of establishing a $17^{\text {th }}$ voivodeship (Central Pomerania) in economic, spatial-functional and social terms. The region, in the opinion of the proponents of its restoration as an independent self-governing voivodeship, would acquire better access to EU means and could follow its own development path more dynamically than the area has done so far.

46 It would be worth exploring a conception of a metropolitan reform in Poland, preferably in stages, from metropolitan associations to metropolitan poviats, assuming great elasticity of territorial and systemic solutions at the scale of the country (monoand polycentric agglomerations).

47 When thinking about possible changes in the territorial division, one should consider an option of combining urban and rural poviats, primarily in poorly populated areas and ones with a strong concentration of service infrastructure in a central town. All changes should be preceded by experts' and social debates. The solutions justified on their merits and that have obtained social acceptance can be implemented in stages or by way of administrative experiments. An experiment in administration usually involves testing more complex changes (reforms) and their implementation in selected administrative units (as a rule better prepared for changes, e.g. large cities). It can also be implemented in all units, but in a limited area (e.g. in regions more efficient in administrative terms). An experiment allows observing the results of the reform and introducing corrections in its implementation in the next units (Kaczmarek, 2005).

Territorial structures, if they are a stiff corset in which territorial governments perform public tasks, not always adjusted to their size, can also undergo elastic changes. That is why, when setting up a spatial framework for the operation of territorial corporations, one should allow for possibilities or variants of those tasks performed in other spatial systems complementary to the basic administrative division and using all forms of inter-territorial cooperation. An ad hoc elastic territorial framework can help to deal with matters at hand, without meeting the requirement of either permanence or stability. Legal rules permitting the setting up of bottom-up territorial associations are evidence of the decentralisation of administration and trust for territorial self-governments. 


\section{BIBLIOGRAPHIE}

Chojnicki Z., Czyż T., 2000. Nowa organizacja terytorialna Polski i układ regionalny. Czasopismo Geograficzne, $n^{\circ}$ 3-4.

Consolidation or fragmentation? The size of local government in Central and Eastern Europe, 2002. Local Government and Public Service Reform Initiative, Open Society Institute. Ed. P. Swianiewicz, Budapest.

Gustafsson A., 1992. Samorząd terytorialny w Szwecji. Fundacja Rozwoju Demokracji Lokalnej, Szczecin.

Hausner J., 2013. Raport o stanie samorzĄdności terytorialnej w Polsce. Uniwersytet Ekonomiczny w Krakowie, Małopolska Szkoła Administracji Publicznej, Kraków.

Heinelt H., Kübler D, 2005. Metropolitan governance. Capacity, democracy and the dynamics of place. Routledge. London/New York.

Hoffmann K., Jacob J., 1980. Raumordnungspolitische Bestimmungsfaktoren und Auswirkungen der kommunalen Neugliederung. In H. Zieliński: Lokale Politik zwischen Eigenständigkeit und staatlicher Abhängigkeit. Empirische analysen zu Handlungsspielräumen, Gebietsreformen und zur Selbstverwaltung. Sozialwissenschaftliche Studien zur Stadt- und Regionalpolitik, bd. 13.

Izdebski H., 2012. Dylematy Ustawy Metropolitalnej. Referat wygłoszony na konferencji Polskie Metropolie, dokonania i kierunki rozwoju, 19.04. 2012, Poznań.

Izdebski. H., 2009. Samorząd terytorialny. Podstawy ustroju i działalności. LexisNexis, Warszawa.

Jouve B., Lefevre C.,2000. Local Power, Territory and Institutions in European Metropolitan Regions. Frank Cass, London.

Kaczmarek T., 2001. Reforma terytorialno-administracyjna Polski - porównanie z krajami Unii Europejskiej. In T. Czyż: Zróżnicowanie społeczno-gospodarcze w nowym układzie terytorialnym Polski. Biuletyn KPZK PAN, z. 197.

Kaczmarek T., 2005. Struktury terytorialno-administracyjne $i$ ich reformy $w$ krajach europejskich (The territorial-administrative structures and their reforms in European states). Wydawnictwo Naukowe UAM, Poznań.

Kaczmarek T., Ryder A., 2015. Top-down and bottom-up metropolitan integration in Poland. In J.Bucek, A. Ryder: Governence in transition. Springer. Dordrecht.

Karliński W., Nelicki A., Płoskonka J., 2000. Polska powiatowa w roku 1999 - ogólna charakterystyka. Samorząd Terytorialny, $\mathrm{n}^{\circ} 9$.

Keating M., 1995. Size, efficiency and democracy: Consolidation, fragmentation and public choice. In D. Judge, G. Stoker, H. Wolman: Theories of urban politics. London.

Lutrzykowski A. Ustrój terytorialny państwa a decentralizacja systemu władzy publicznej.

Wydawnictwo Adam Marszałek, Torun.

Miszczuk A., 2003. Regionalizacja administracyjna III Rzeczpospolitej. Koncepcje teoretyczne a rzeczywistość. Wydawnictwo Uniwersytetu Marii Curie-Skłodowskiej, Lublin.

Mouritzen P.-E., 1989. City size and citizen's satisfactions: two competing theories revisited. European Journal of Political Research, 17. 
Norris D., 2001. Whither metropolitan governance? Urban Affairs Review, 36.

Ocena nowego zasadniczego podziału terytorialnego państwa, 2001. SamorzĄd Terytorialny, nr 4.

Reforma terytorialnej organizacji kraju: dwa lata doświadczeń (Eds. G. Gorzelak, B. Jałowiecki, M. Stec). Wydawnictwo Naukowe Scholar. Warszawa.

Ocena sytuacji samorzĄdów lokalnych. 2013. Ministerstwo Administracji i Cyfryzacji, Warszawa.

Partacz Cz., 2005. SamorzĄdność czy woluntaryzm centrali? Walka społeczności koszalińskosłupskiej o utworzenie województwa środkowopomorskiego. Rocznik Koszaliński, 33, Koszalińska Biblioteka Publiczna im. Joachima Lelewela, Koszalin.

Sack R.D., 1986. Human territoriality: its theory and history. Cambridge University Press, Cambridge.

Sharpe J., 1995. Summary of the debates. The size of municipalities, efficiency and citizen participation. Local and regional authorities in Europe, $\mathrm{n}^{\circ} 56$, Council of Europe Press.

Swianiewicz P., 2002. Modele samorzĄdu terytorialnego w krajach Europy Zachodniej oraz Środkowo-Wschodniej. Próba generalizacji. Studia Regionalne i Lokalne, nr 4 (10).

Swianiewicz P., 2010. Territorial consolidation reforms in Europe. Local Government and Public Service Reform Initiative. Open Society Institute, Budapest.

Szmytkie R., 2009. Miasta-zlepieńce na ŚlĄsku Dolnym i Opolskim. Instytut Geografii i Rozwoju Regionalnego Uniwersytetu Wrocławskiego, Wrocław.

Walczak D., 2012. Konieczność zmian w podziale terytorialnym gmin. Zeszyty Naukowe SGGW, Ekonomika i Organizacja Gospodarki Żywnościowej, Warszawa.

Zaborowski Ł., 2009. Podział terytorialny Rzeczpospolitej - spojrzenie krytyczne. Prace Geograficzne, 121, Uniwersytet Jagielloński, Kraków.

\section{NOTES}

1. Territorial self-governance existed in Poland at the level of communes in the interwar period 1919-1939. After the Second World War it was abolished and replaced, in the years 1950-1989, by national councils as an element of centralised state administration.

2. The Resolution of the Senate of the Polish Republic of 11 January 2001 assessing the state's new basic territorial division.

3. As Swianiewicz (2002) observes, because of the authoritarian character of territorial changes in the countries of feasible socialism, it should not come as a surprise that right after 1990 in some of them there appeared strong bottom-up pressure for autonomy on the part of localities that had been forcibly included into larger units.

\section{RÉSUMÉS}

This article seeks to present the chief features of Poland's territorial division and assess it at its three levels: voivodeships, poviats and communes. The reference point is the territorial divisions of other EU states, especially those that, like Poland, have a three-tier structure. The basic thesis 
is that the territorial organisation of public administration should change so as to keep up with political, economic, social and spatial processes, the last being especially important for it. The article closes with recommendations for ways of changing local and regional administrative structures, like establishing a new voivodeship and metropolitan poviats, combining urban and rural poviats, and fusions of communes.

\section{INDEX}

Keywords : Poland, administrative division, administrative reform, commune, poviat, voivodeship, metropolitan area.

Thèmes : Sur le Champ - Sur le Terrain

\section{AUTEUR}

\section{TOMASZ KACZMAREK}

Tomasz Kaczmarek, tomkac@amu.edu.pl, is Director of the Centre for Metropolitan Studies, Head of the Department of Settlement Systems and Territorial Organisation in the Institute of SocioEconomic Geography and Spatial Management of Adam Mickiewicz University in Poznań (Poland). Member of the Committee for Space Economy of the Polish Academy of Sciences. Member of the Steering Committee of the International Geographical Union's Commission on Geography of Governance. Editor-in-chief of the Poznań Agglomeration Library editorial series. Member of the editorial boards of the foreign journals Geospace and Europa Regional. 